\title{
Pengetahuan Apoteker tentang Obat-Obat Look-alike Sound-alike dan Pengelolaannya di Apotek Kota Yogyakarta
}

\author{
Muhammad Muhlis, Resa Andyani, Tika Wulandari, Aulisa A. Sahir \\ Fakultas Farmasi, Universitas Ahmad Dahlan, Yogyakarta, Indonesia
}

\begin{abstract}
Abstrak
Perkembangan produksi obat yang cukup pesat menyebabkan terdapat beberapa obat yang memiliki bentuk dan nama yang hampir sama, hal ini dapat menyebabkan munculnya medication error berupa kesalahan dalam pemberian obat kepada pasien. Obat yang hampir sama bentuk dan namanya ini dikenal dengan obat-obat look-alike sound-alike (LASA). Penelitian observasional ini bertujuan untuk mengetahui sejauh mana pengetahuan apoteker yang bekerja di apotek Kota Yogyakarta terhadap obatobat LASA dan apakah apotek tersebut telah melaksanakan penataan obat berdasarkan kaidah obat LASA. Hasil penelitian kemudian diuji menggunakan Chi-Square untuk mengetahui hubungan antara pengetahuan dan pengelolaan obat LASA serta pengelolaan dan kesalahan pengambilan obat LASA. Pengambilan data dilakukan pada bulan September-November 2018. Total sampling adalah apotek di kota Yogyakarta yang bersedia menjadi tempat penelitian dan objek penelitian adalah apoteker yang bekerja di masing-masing apotek dan telah menandatangani informed consent. Dari 136 apotek yang berada di kota Yogyakarta, 66 apotek bersedia menjadi objek penelitian dan mengisi kuesioner dengan benar. Pengetahuan apoteker yang bekerja di apotek Kota Yogyakarta terhadap obat LASA berkategori baik $56 \%$ dan kurang baik $44 \%$; pengelolaan obat LASA berkategori baik $41 \%$ dan kurang baik $59 \%$; dan pengalaman dalam kesalahan pengambilan obat LASA berkategori pernah $53 \%$ dan tidak pernah 47\%. Hasil uji Chi-Square menyatakan tidak ada hubungan yang bermakna antara pengetahuan dan pengelolaan obat LASA serta antara pengelolaan dan kesalahan dalam pengambilan obat LASA.
\end{abstract}

Kata kunci: Apotek, apoteker, obat-obat look-alike sound-alike (LASA)

\section{Pharmacist Knowledge of Look-alike Sound-alike Drugs and Their Management at Pharmacies in the City of Yogyakarta}

\begin{abstract}
Drugs production develop rapidly nowadays and many drugs have embodied similar shapes and names which may lead to medication error and difficulty in emergency medication administration. Drugs with similar shapes/physical appearances/packagings and names that have spelling similarities are known as look-alike sound-alike (LASA) medicines. This observational study aimed to determine the extent of the knowledge of pharmacists on LASA drugs at pharmacies in the city of Yogyakarta, and whether the pharmacies have implemented drugs structuring according to the LASA drug rules. The results were analyzed using Chi-Square test to determine the relationship between knowledge and management of LASA drugs, and between the management and errors in taking LASA drugs. Data retrieval was carried out in September-November 2018 with total sampling were pharmacies in the city of Yogyakarta and objects of research were pharmacists who worked at the sampling pharmacies and had signed the informed consent. Of the 136 pharmacies, only 66 pharmacies were willing to become the samples of research. The results showed that pharmacists' knowledge on LASA drugs categorized as good was $56 \%$ and not good was $44 \%$; LASA drugs management categorized as good was $41 \%$ and not good was $59 \%$; pharmacists who had experience in errors in taking LASA drugs was $53 \%$ and never had was $47 \%$. In conclusion, there was no significant relationship between knowledge and management of LASA drugs, and between management and errors in taking drugs LASA drugs.
\end{abstract}

Keywords: Look-alike sound-alike drugs, pharmacist, pharmacy

Korespondensi: Muhammad Muhlis, S.Si., Apt., Sp.FRS., Fakultas Farmasi, Universitas Ahmad Dahlan, Yogyakarta, D.I. Yogyakarta 55164, Indonesia, email: muhlis3@yahoo.co.id

Naskah diterima: 22 Januari 2019, Diterima untuk diterbitkan: 17 April 2019, Diterbitkan: 28 Juni 2019 


\section{Pendahuluan}

Apotek merupakan suatu sarana pelayanan kefarmasian tempat dilakukannya praktik kefarmasian oleh apoteker. ${ }^{1}$ Apoteker adalah sarjana farmasi yang telah lulus sebagai apoteker dan telah mengucapkan sumpah jabatan apoteker. ${ }^{1}$ Penyelenggaraan standar pelayanan kefarmasian di apotek selayaknya harus didukung ketersediaan sumber daya kefarmasian dan didukung oleh pengetahuan yang selalu terbaharukan, serta berorientasi kepada keselamatan pasien. Menurut UndangUndang yang berlaku, apoteker mempunyai kewenangan dalam melakukan pelayanan kefarmasian yang berupa pelayanan langsung serta bertanggung jawab kepada pasien yang berkaitan dengan sediaan farmasi (obat, bahan obat, obat tradisional dan kosmetika) untuk mencapai hasil yang maksimal dalam rangka meningkatkan mutu kehidupan pasien. Salah satu aspek dalam pelayanan farmasi di apotek adalah pelayanan dispensing obat atau lebih dikenal sebagai pelayanan obat untuk pasien, baik obat swamedikasi maupun obat atas resep dokter.

Perkembangan industri farmasi saat ini sangatlah pesat dan berakibat pada banyaknya obat yang beredar, sehingga satu obat generik dapat memiliki banyak obat patennya dan terkadang bentuk dan nama obat satu dengan yang lain menjadi sama atau hampir sama. Bentuk dan atau nama obat yang hampir sama dapat menyebabkan terjadinya medication error yang berupa kesalahan dalam pemberian obat kepada pasien. Obat yang hampir sama bentuk dan namanya dikenal dengan obatobat look-alike sound-alike (LASA). Adanya pengetahuan apoteker untuk menyikapi obatobat LASA di sarana distribusi obat adalah salah satu upaya dalam mencegah munculnya medication error. Adapun kesalahan dalam penggunaan obat-obat LASA belum banyak dilaporkan dalam literatur maupun publikasi. ${ }^{2}$

Dalam hal penyimpanan obat di apotek, apoteker harus memastikan penyimpanan obat dan bahan medis habis pakai disimpan sesuai dengan peraturan yang berlaku, antara lain: ${ }^{1} 1$ ) Obat/bahan obat harus disimpan dalam wadah asli dari pabrik. Dalam hal pengecualian atau darurat saat isi dipindahkan pada wadah lain, maka harus dicegah terjadinya kontaminasi dan harus ditulis informasi yang jelas pada wadah baru. Wadah ini sekurang-kurangnya memuat nama obat, nomor batch dan tanggal kadaluwarsa; 2) Semua obat/bahan obat harus disimpan pada kondisi yang sesuai sehingga terjamin keamanan dan stabilitasnya; 3) Sistem penyimpanan obat dilakukan dengan memperhatikan bentuk sediaan, dan kelas terapi obat serta disusun secara alfabetis; 4) Pengeluaran obat memakai sistem first expire first out (FEFO) dan first in first out (FIFO).

Penataan penyimpanan obat hendaknya memperhatikan obat LASA yang terkadang dapat menimbulkan medication error akibat kesalahan pengambilan dari rak penyimpanan obat. Perlu dikembangkan sistem manajemen penataan obat untuk mengatasi medication error tersebut. Identifikasi obat-obat LASA, kebijakan penggunaan obat high alert dan kebijakan penulisan resep yang aman juga memberikan kontribusi signifikan terhadap pengurangan insiden kesalahan medication error di rumah sakit. ${ }^{3}$ Faktor risiko umum terkait obat-obat LASA meliputi: 1) Tulisan tangan yang tidak terbaca; 2) Pengetahuan yang tidak lengkap tentang nama obat; 3) Produk baru yang tersedia; 4) Kemasan atau pelabelan yang serupa; 5) Potensi, bentuk sediaan, dan frekuensi pemberian yang serupa; dan 6) Penggunaan klinis yang mirip. Contoh obat LASA dapat dilihat pada Tabel 1.

Apoteker harus memastikan bahwa pasien menerima obat yang benar sesuai dengan yang diresepkan oleh dokter. Berbagai upaya yang dapat dilakukan apoteker untuk menghindari kesalahan pengambilan obat antara lain: ${ }^{4} 1$ ) Memisahkan obat LASA dengan obat-obatan lainnya; 2) Menyediakan sebuah instalasi 
sistem peringatan pada komputer atau pada kemasan; 3) Melakukan pemeriksaan obat dua kali (double-checking); 4) Menghubungi dokter untuk melakukan klarifikasi resep; dan 5) Menghafal berbagai obat LASA. Menurut Singh et al., cara menyimpan obat-obat LASA antara lain: ${ }^{5}$ 1) Obat-obat LASA tidak boleh ditumpuk bersama dengan obat lain; 2) Obatobat LASA harus disimpan secara terpisah di dua baris pada rak obat: obat kelompok I dalam satu baris dan kelompok II di baris lain untuk menghindari kesalahan pengobatan; 3) Di bangsal, ruang darurat, dan operasi, obat LASA harus disimpan di tempat obat atau kotak obat terpisah; 4) Di apotek atau toko obat, daftar obat LASA harus digantung di kedua rak; dan 5) Di bangsal/unit, daftar obat LASA harus ditempelkan di dalam ruang obat, dan jika perlu, di tempat perawatan.

Tabel 1 Contoh Obat Golongan LASA

\begin{tabular}{cc}
\hline \multicolumn{2}{c}{ Nama Obat LASA } \\
\hline Cisplatin & Carboplatin \\
Humalog & Humulin \\
Homalog & Novolog \\
Mefinter & Metifer \\
Leschol & Lesichol \\
\hline
\end{tabular}

Tabel 2 Contoh Penulisan Tall Man Lettering pada Obat LASA

\begin{tabular}{cc}
\hline \multicolumn{2}{c}{ Nama Obat LASA } \\
\hline CISplatin & CARBOplatin \\
HumALOG & HumULIN \\
HOMAlog & NOVOlog \\
MEFINter & METIfer \\
LESchol & LESIchol \\
ChlorproMAZINE & ChlorproPAMIDE \\
LOsEC & LAsIX \\
volDILex & volTADex \\
TetrIN & TetrIS \\
ChlorproMAZINE & ChlorproPAMIDE \\
IOsEC & lAsIX \\
volDILex & volTADex \\
TetrIN & TetrIS \\
\hline
\end{tabular}

Dalam melakukan penyimpanan terhadap obat-obat LASA, dapat digunakan Tall Man lettering untuk menekankan perbedaan pada obat yang memililki nama atau pengucapan suara yang sama. Tall Man lettering digunakan pada penulisan nama obat untuk menyoroti bagian perbedaan utamanya dan membantu membedakan nama-nama yang mirip. Beberapa penelitian telah menunjukkan bahwa metode Tall Man lettering dapat membuat nama obat yang mirip lebih mudah untuk dibedakan, dan lebih sedikit kesalahan yang dibuat ketika menggunakan huruf besar untuk penulisan nama yang berbeda dan huruf kecil untuk nama yang mirip. ${ }^{6}$ Contoh penulisan dengan menggunakan Tall Man lettering dapat dilihat pada Tabel 2.

Masing-masing komponen di dalam institusi memiliki peran untuk mengurangi tingkat kesalahan dalam pengambilan obat-obatan LASA. ${ }^{7}$ Peran dokter antara lain: 1) Memiliki banyak pengalaman dengan nama generik dan nama merek yang tersedia di daerah lokal mereka; 2) Menentukan dengan jelas bentuk sediaan, kekuatan obat dan petunjuk lengkap pada resep; 3) Menggunakan nama merek dan generik saat menulis resep; 4) Menyertakan tujuan obat di dalam resep; 5) Menghindari perintah lisan dan tidak meresepkan melalui telepon; 6) Menghindari penggunaan istilah obat yang membingungkan; dan 7) Menulis resep obat dengan tulisan tangan yang dapat dibaca. Peran apoteker antara lain: 1) Merujuk kembali ke dokter jika kebingungan dan harus memiliki pengetahuan dasar tentang rejimen dosis, setidaknya untuk obat-obat yang biasa digunakan; 2) Memasang suatu pengingat yang terkomputerisasi untuk pasangan nama yang sering membingungkan sehingga peringatan ini diperhatikan saat mengambil kedua obat tersebut, dan menempelkan stiker label 'LASA' ke area penyimpanan produk tersebut. Peran pasien di antaranya: 1) Mengonfirmasi nama dan kekuatan obat yang diresepkan sebelum meninggalkan dokter; dan 2) Memverifikasi 
nama dan instruksi penggunaan obat apabila pasien buta huruf. Pihak produsen juga dapat turut berperan di dalam proses produksi obat LASA, dengan cara: 1) Melakukan pengemasan label dan kode warna obat dengan tepat; 2) Memberi nama obat-obat OTC dengan nama yang unik; 3) Menanggapi laporan terkait kebingungan pihak konsumen dengan serius; dan 4) Menggunakan model penulisan Tall Man lettering pada nama obat yang hampir sama, contohnya DOBUTamine, DOPamine. Food and Drug Administration (FDA) dapat berperan dalam: 1) Menggunakan perangkat lunak komputer untuk menganalisis tingkat kemiripan nama suatu obat yang baru dengan obat yang sudah ada di pasaran. Nama yang berpotensi membingungkan ditolak. Untuk meminimalkan kebingungan antara nama obat-obat yang mirip, FDA meninjau sekitar 300 nama merek setiap tahunnya sebelum dipasarkan, dan sekitar sepertiganya ditolak; 2) Mendorong apoteker dan tenaga profesional kesehatan lainnya untuk melaporkan setiap kesalahan pengobatan baik yang aktual atau potensial kepada Adverse Event Reporting System di pemerintah; dan 3) Mendorong otoritas perizinan dan badan pengatur untuk melakukan kontrol lebih besar atas penamaan formulasi baru.

Penelitian ini bertujuan untuk mengetahui sejauh mana pengetahuan apoteker terhadap pengelolaan dan penataan obat obat LASA di apotek. Selain itu, diteliti hubungan antara pengetahuan dan pengelolaan obat LASA, dan hubungan antara pengelolaan obat LASA dan kesalahan dalam pengambilan obat.

\section{Metode}

Penelitian ini telah memperoleh persetujuan kelaikan etik dari Komite Etik Penelitian Universitas Ahmad Dahlan dengan nomor surat 011812143 dan dilaksanakan pada bulan September sampai dengan November 2018. Penelitian ini dirancang secara observasional dan dianalisis secara analitik menggunakan uji Chi-Square untuk mengetahui hubungan antara pengetahuan dan pengelolaan obat-obat LASA, dan antara pengelolaan dan kesalahan pengambilan obat-obat LASA. Objek penelitian ini adalah apoteker yang bekerja di apotek wilayah Kota Yogyakarta, serta bersedia untuk menjadi responden penelitian ini, dibuktikan dengan penandatanganan informed consent dan pengembalian lembar pertanyaan yang telah diisi dengan lengkap.

Instrumen yang digunakan pada penelitian ini adalah kuesioner berupa daftar pertanyaan yang harus diisi oleh apoteker penanggung jawab apotek atau apoteker pendamping. Hasil kuesioner digunakan untuk mengukur pengetahuan apoteker terhadap obat LASA, penyimpanan obat LASA, serta penulisan etiket di rak obat untuk obat LASA. Kuesioner berisi daftar 5 item pertanyaan yang dapat dilihat pada Tabel 3 .

\section{Hasil}

Jumlah apotek yang masih beroperasi di kota Yogyakarta berdasarkan penelitian Sukamdi et al. adalah 116 apotek, dan terdapat beberapa apotek yang sudah tidak beroperasional lagi. ${ }^{8}$ Berdasarkan hasil penyebaran kuesioner ke apotek-apotek yang berada di wilayah kota Yogyakarta, hanya 66 apotek yang bersedia menjadi objek penelitian dan mengembalikan kuesioner yang sudah diisi lengkap. Adapun apotek yang tidak bersedia menjadi objek penelitian menolak dengan alasan antara lain belum mendapatkan izin dari pemilik apotek, apoteker sulit untuk ditemui, serta apotek tidak bersedia tanpa alasan pasti.

Berdasarkan data hasil kuesioner (Tabel 4), dapat diketahui bahwa apoteker di sebanyak 37 apotek (56\%) mempunyai pengetahuan tentang obat LASA berkategori baik. Namun, lebih dari setengah total sampel apotek, yakni 39 apotek (59\%) mempunyai pengelolaan obat LASA yang berkategori kurang baik. 
Tabel 3 Pertanyaan untuk Mengukur Pengetahuan Apoteker tentang Obat LASA

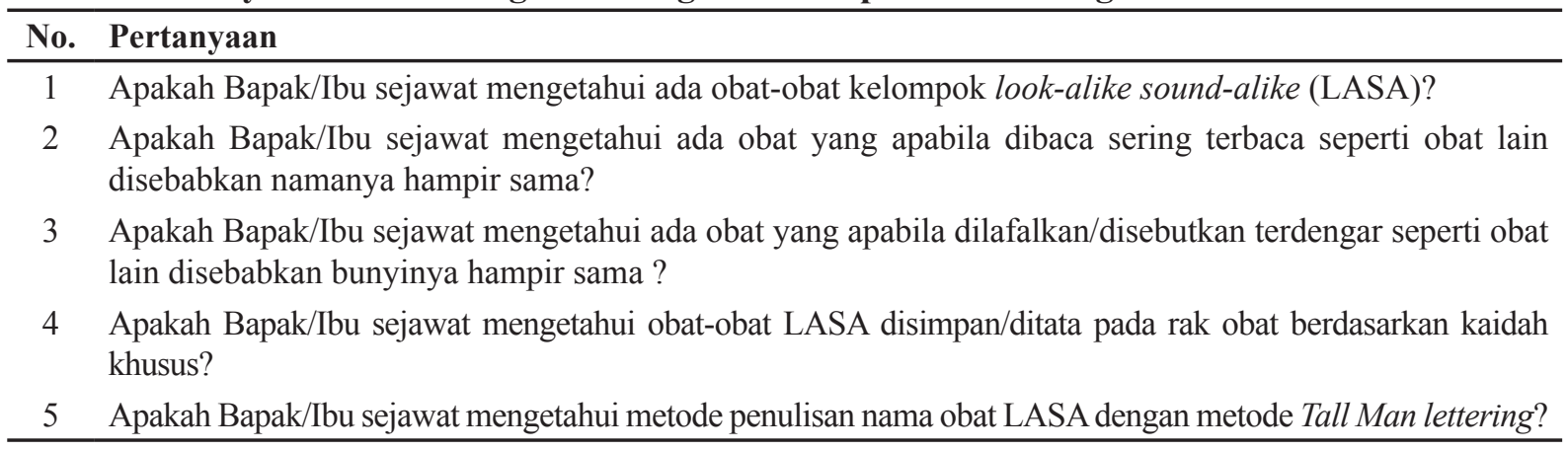

Sebanyak 35 apotek (53\%) memiliki apoteker yang berpengalaman berbuat kesalahan dalam pengambilan obat LASA.

Uji statistik dilakukan menggunakan uji Chi-Square dengan taraf signifikansi 0,05 , dan hasil ujinya dapat dilihat pada Tabel 5. Dari hasil uji Chi-Square, dapat disimpukan bahwa tidak ada hubungan yang bermakna antara pengetahuan apoteker dan pengelolaan obat LASA oleh apoteker $(\mathrm{p}=0,660)$, serta tidak ada hubungan yang bermakna antara pengelolaan obat LASA dan kesalahan dalam pengambilan obat LASA $(p=0,096)$.

\section{Pembahasan}

Penelitian ini baru dilaksanakan terhadap sebanyak 48,5\% apoteker yang bekerja di apotek wilayah Kota Yogyakarta, dan belum menjangkau apoteker yang bekerja di fasilitas pelayanan kefarmasian lainnya seperti rumah sakit dan puskesmas. Hasil dari pengukuran pengetahuan apoteker terhadap obat LASA yang berkategori baik mencapai 56\%, artinya sebagian besar apoteker telah mempunyai pengetahuan yang memadai mengenai obatobat LASA. Namun demikian, sebanyak 59\% apoteker memiliki pengelolaan obat LASA yang kurang baik. Hal ini dapat dilihat dari belum diterapkannya pelabelan obat LASA berdasarkan Tall Man lettering.

Hasil uji Chi-Square menunjukkan tidak ada hubungan bermakna antara pengetahuan dan pengelolaan obat LASA. Penataan dan pelabelan obat LASA, jika tidak dilakukan, cenderung berujung pada pengambilan obat yang salah atau medication error disebabkan adanya kemiripan pada penulisan nama obat.

Tabel 4 Hasil Penelitian

\begin{tabular}{llcc}
\hline Variabel & \multicolumn{1}{c}{ Kriteria } & Jumlah & Total (\%) \\
\hline Pengetahuan obat LASA & Baik & 37 & 56 \\
& Kurang baik & 29 & 44 \\
Pengelolaan obat LASA & Baik & 27 & 41 \\
& Kurang baik & 39 & 59 \\
Kesalahan dalam pengambilan obat LASA & Tidak pernah & 31 & 47 \\
& Pernah & 35 & 53 \\
Lama bekerja apoteker (tahun) & $<5$ & 40 & 61 \\
Usia apotek (tahun) & $>5$ & 26 & 39 \\
Durasi kehadiran apoteker di apotek (jam) & $<5$ & 24 & 36 \\
& $>5$ & 42 & 64 \\
\hline
\end{tabular}


Tabel 5 Hasil Uji Chi-Square

\begin{tabular}{lcc}
\hline \multicolumn{1}{c}{ Variabel Uji } & Nilai p & Interpretasi (Signifikan jka p<0,05) \\
\hline Pengetahuan dan pengelolaan obat LASA & 0,660 & Tidak ada hubungan yang bermakna \\
Pengelolaan dan kesalahan pengambilan obat LASA & 0,096 & Tidak ada hubungan yang bermakna \\
\hline
\end{tabular}

Penelitian yang dilakukan oleh Pitoyo et al. menunjukkan bahwa jenis kasus dispensing error yang terjadi pada pelayananan farmasi rawat jalan instalasi farmasi RS tempat studi di Malang adalah salah obat, salah kekuatan obat, dan salah kuantitas. ${ }^{9}$

Besarnya persentase pengalaman apoteker melakukan kesalahan pengambilan obat LASA mencapai 53\%, namun berdasarkan hasil uji Chi-Square, hal ini tidak memiliki hubungan yang bermakna dengan pengelolaan obatobat LASA. Hasil ini berbeda dengan hasil penelitian serupa yang dilakukan Safiri et al. ${ }^{10}$ mengenai pengelolaan obat-obatan look-alike (rupa mirip) di instalasi rumah sakit $\mathrm{X}$ di kota Cimahi. Hasil penelitian tersebut menyatakan bahwa instalasi farmasi rumah sakit tersebut telah melakukan upaya pencegahan terjadinya kesalahan dalam pemberian obat, yakni dengan cara menempatkan obat golongan look-alike tidak secara alfabetis, namun disusun dengan cara diselingi obat lain dan menempelkan stiker LASA berwarna kuning. Akan tetapi, belum diterapkan penulisan nama obat dengan kaidah Tall Man lettering di RS tersebut.

Penelitian yang dilakukan oleh Tajuddin et al. menyatakan bahwa dispensing error yang terjadi pada sebuah Instalasi Rawat Darurat di rumah sakit yang diteliti disebabkan oleh tulisan resep yang tidak jelas terkait namanama obat yang kemasan dan namanya hampir sama (LASA). Obat-obat LASA ini biasanya ditempatkan pada rak obat yang sama karena penyimpanan obat-obat di apotek disusun dengan berdasarkan abjad. ${ }^{11}$ Hasil penelitian oleh Nilasari et al. menunjukkan bahwa kejadian medication error yang paling banyak yaitu kesalahan pengambilan obat dari rak obat dengan jumlah kejadian yakni sebanyak 6 kali $(1,5 \%)$. Hal tersebut disebabkan obat- obat yang termasuk kategori LASA letaknya berdekatan satu dengan yang lain. ${ }^{12}$ Berbeda dengan hasil penelitian oleh Ciociano et al., medication error pada penanganan obat-obat LASA yang tidak sesuai prosedur sebagian besar terjadi pada kasus yang melibatkan adanya kesalahan dosis (40,9\%), kesalahan obat $(16 \%)$, dan kesalahan rute pemberian (9,5\%). Penyebab kesalahan ini dikategorikan sebagai miskomunikasi lisan dan tertulis, kebingungan nama (misal nama yang mirip atau mirip), data laboratorium yang mirip atau "menyesatkan", jeleknya kinerja atau pengetahuan, serta kemasan atau desain obat yang tidak sesuai. ${ }^{13}$ Penelitian yang dilakukan Chanakit et al. pada tahun 2010 di rumah sakit di Thailand menunjukkan bahwa studi yang telah dilakukan berhasil mengidentifikasi 5.327 pasangan obat LASA: bentuk tablet/ kapsul paling sering muncul $(3.695 ; 69,36 \%)$, diikuti oleh injeksi $(944 ; 17,72 \%)$, preparat obat luar $(367 ; 6,89 \%)$, preparat cairan $(307$; $5,76 \%)$ dan obat kemoterapi $(14 ; 0,26 \%)$; semua obat tersebut berpotensi menyebabkan kesalahan pengambilan obat. ${ }^{14}$

\section{Simpulan}

Apoteker yang bekerja di apotek wilayah Kota Yogyakarta memiliki pengetahuan terhadap obat LASA berkategori baik sebesar 56\% dan kurang baik 44\%, memiliki pengelolaan obat LASA berkategori baik sebesar $41 \%$ dan kurang baik 59\%, serta memiliki pengalaman melakukan kesalahan dalam pengambilan obat LASA sebesar 53\% dan yang tidak pernah melakukan kesalahan sebesar 47\%. Tidak ada hubungan bermakna antara pengetahuan dan pengelolaan obat LASA, dan tidak ada hubungan bermakna antara pengelolaan dan 
kesalahan dalam pengambilan obat LASA.

\section{Pendanaan}

Penelitian ini tidak didanai oleh sumber hibah manapun.

\section{Konflik Kepentingan}

Seluruh penulis menyatakan tidak terdapat potensi konflik kepentingan dengan penelitian, kepenulisan (authorship), dan atau publikasi artikel ini.

\section{Daftar Pustaka}

1. Kementerian Kesehatan Republik Indonesia. Peraturan Menteri Kesehatan Republik Indonesia Nomor 9 Tahun 2017 Tentang Apotek. Jakarta: Kementerian Kesehatan Republik Indonesia; 2017.

2. Naunton M, Gardiner HR, Kyle G. Lookalike, sound-alike medication errors: A novel case concerning a Slow-Na, Slow-K prescribing error. Int Med Case Rep J. 2015;8:51-3. doi: 10.2147/IMCRJ.S78637

3. Nambiar BC, Das AK., Chakravarty A. Medication error: An unfortunate reality. Med J Armed Forces India. 2016;72(3): 297-8. doi: 10.1016/j.mjafi.2015.0 4.0 11

4. Australian Commission on Safety and Quality in Health Care. Submission to the consultation on the TGA Medicine Labelling and Packaging Review [diunduh 1 November 2018]. Tersedia dari: https:// www.tga.gov.au/sites/default/files/consul t-labelling-packaging-review-120524-su bmission-acsqhc.pdf

5. Singh S, Singh AR. Policies and procedures for sound-alike and look-alike. Int J Res Found Hosp Healthcare Adm. 2017; 5(1): 15-20.doi: 10.5005/jp-journals-10035-1071

6. Grissinger $M$. Tall man letters are gaining wide acceptance. P T. 2012;37(3):132-3,
7. Keny MS, Rataboli PV. Look-alike and sound-alike drug brand names: A potential risk in clinical practice. Indian $\mathrm{J}$ Clin Pract. 2013;23(9):8-13.

8. Sukamdi DP, Lazuardi L, Sumarni S. Analisis distribusi apotek dengan sistem informasi geografis. J Manag Pharm Pract. 2015;5(1):56-60. doi: 10.22146/jmpf.29

9. Pitoyo AZ, Hariyanto T, Yuliansyah N, Mauludiyah I. Kebijakan sistem penyimpanan obat LASA, alur layanan, dan formulir untuk mencegah dispensing error. J Kedokt Brawijaya. 2016;29(3): 235-44. doi: 10.21776/ub.jkb.2016.029.03.1

10. Safiri M, Zazuli Z, Dentiarianti. Studi pengelolaan obat-obatan look alike (rupa mirip) di instalasi farmasi Rumah Sakit X di Kota Cimahi. Prosiding Seminar Nasional Farmasi (SNIFA) 2 UNJANI; 3 November 2016; Bandung, Indonesia. Indonesia: Universitas Jendral Ahmad Yani; 2016.

11. Tajuddin RS, Sudirman I, Maidin A. Faktor penyebab medication error di Instalasi Rawat Darurat. J Manaj Pelayanan Kesehat. 2012;15(4):182-7,

12. Sari PN, Hasan D, Uun HW. Faktorfaktor yang berkaitan/berhubungan dengan medication error dan pengaruhnya terhadap patient safety yang Rawat Inap di RS. Pondok Indah Jakarta, tahun 2012-2015. Soc Clin Pharm Indones J. 2017; 2(1):1-9.

13. Ciociano N, Grisi L, Bagnasco L, Elberti MG, Mazzarella M. Risk assessment of look-alike, sound-alike (LASA) medication errors in an Italian hospital pharmacy: A model based on the 'Failure Mode and Effect Analysis'. J Health Soc Sci. 2017; 2(1):47-64. doi: 10.19204/2017/rsks4

14. ChanakitT, Napaporn J, Chiempattanakajohn T, Sangkhawan, S, Wichakot S. The survey of look alike/sound alike (LASA) drugs available in hospitals in Thailand. Afr $\mathrm{J}$ Pharm Pharmacol. 2013:7(6):227-39. doi: 10.5897/AJPP11.812 